\title{
Impacts of Adapted Altitude on Yield and Some Others Characteristics of Bituminaria bituminosa
}

\author{
Zeki Acar ${ }^{1, a, *}$, İknur Ayan ${ }^{1, b}$, Mehmet Can $^{1, c}$, Gülcan Kaymak ${ }^{1, d}$ \\ ${ }^{1}$ Department of Agronomy, Agricultural Faculty, Ondokuz Mayls University, 55270 Atakum/Samsun, Turkey
}

*Corresponding author

\begin{tabular}{|c|c|}
\hline A R T I C L E I N F O & A B S T R A C T \\
\hline $\begin{array}{l}\text { Keywords: } \\
\text { Bituminaria bituminosa } \\
\text { Altitude } \\
\text { Spring and autumn elongation } \\
\text { Correlation } \\
\text { Yield }\end{array}$ & $\begin{array}{l}\text { This study was carried out with } 86 \text { Bituminaria bituminosa (Bitbit) genotypes collected from Central } \\
\text { Black Sea Region of Northern Anatolia in Samsun in 2012. After cleaning, seeds scarifying with } \\
\text { sandpaper and sown in small pots. In November of 2012, the seedlings were transplanted to } \\
\text { experimental field. No fertilizer and water applied throughout the study and spring and autumn } \\
\text { elongation, hay yield and harvesting number in the second year of the plants (2014) were observed } \\
\text { during the study. According to correlation analysis, there was a negative and statistically significant } \\
\text { linear correlation between altitude and spring elongation, autumn elongation, harvest number. There } \\
\text { was also a negative statistically insignificant correlation between altitude and hay yield. A positive } \\
\text { and significant correlation was found between hay yield and spring and autumn elongations, harvest } \\
\text { number; between spring and autumn elongations and number of harvest. Some genotypes taken from } \\
\text { high altitudes stayed dormant in winter period, furthermore they started elongation later than the } \\
\text { others and a slight growth was recorded in autumn. In the light of these results, it is possible to } \\
\text { improve cultivars for different ecological conditions. }\end{array}$ \\
\hline
\end{tabular}


These advantages add up to the other environmental services of legumes:

- High levels of legumes reduce greenhouse gas (GHG) emission $\left(\mathrm{CO}_{2}, \mathrm{~N}_{2} \mathrm{O}\right)$ compared with agricultural systems based on mineral $\mathrm{N}$ fertilization

- They improve sequestration of carbon in soils

- They allow the reduction of the overall fossil energy inputs in the system

- They lessen the release of methane emissions per unit of animal production when present in the diet, contributing to mitigate climate change (Lüscher et al., 2014).

In regions with Mediterranean climates, insufficient forage availability and its low quality over summer and autumn months severely affect the profitability and sustainability of livestock production (Cosentino et al., 2013; Porqueddu et al., 2016). In these environments, summer drought favours the predominance of annual species in grasslands (Neeman and Goubitz, 2000) and most perennial forage species show summer dormancy. Lucerne (Medicago sativa L.) is the most frequently grown perennial legume in many rainfed livestock-based farming systems, largely because of its ability to produce fodder over the warmer months in drought prone environments. Nonetheless, its success depends on the availability of deep soils and irrigation to produce satisfactory yields. Moreover, lucerne shows low persistence both under rainfed conditions and under grazing (Annicchiarico et al., 2011; Pecetti et al., 2006). Currently, there is the need to overcome the constraints associated with lucerne crops to adapt farming systems to climate change scenarios in the Mediterranean climate areas. Lower rainfall, together with greater variability and uncertainty in its distribution, as well as higher air temperatures, are predicted for the $21 \mathrm{st}$ century (Dumont et al., 2015; Giannakopoulos et al., 2009). Another short term perennial forage legume, sainfoin has some problems such as; sensitivity to high temperature and humidity.

In the last years, promising perennial legume species belonging to the genus Bituminaria have been investigated for their high drought tolerance and their ability to remain green also during summer drought in absence of rainfall. The genus Bituminaria has a large geographical distribution in the Mediterranean basin and Macaronesia. Natural distribution of Bitbit is in coastal provinces, located in North, West and South of Anatolia (Davis, 1970; Kilinç et al., 1998; Akçin et al., 2010). The species Bitbit grows in environments ranging from $250-1000 \mathrm{~mm}$ of rainfall and up to $1200 \mathrm{~m}$ of altitude, thanks to its wide genetic diversity (Mendez et al., 2006). Currently, it is exploited as forage resource (hay) in Canary Islands to feed milking goats and as native pasture component in Galilea scrubland (Israel).
The ability of Bitbit to cope with summer drought makes it attractive to improve the resilience of rainfed grazing systems towards climate change and improve their feed security. In this framework, Bitbit could acquire a growing interest in Mediterranean farming systems and species distribution modelling approach can contribute in identifying areas suitable for its cultivation.

The results obtained from a series of research conducted in Australia indicated that Bitbit offers the potential to increase farm profits by up to $26 \%$ and be grown on $28 \%$ of a low rainfall mixed enterprise farm (300 $\mathrm{mm})$. On a high rainfall mixed enterprise farm Bitbit may boost profit by up to $58 \%$ and be grown on $75 \%$ of the farm. The modelled increases in farm profit were large and relate to savings in supplementary feed and higher stocking rates (Finlayson et al., 2012).

The main aim of the study was to determine relationships amongst yield, harvest number, spring and autumn elongation, original altitudes of genotypes. Thus, we could be obtained some information about dormancy characteristics of Bitbit.

\section{Materials and Methods}

Seed samples of 86 Bitbit genotypes were collected from Central Black Sea Region in 2012. Regarding the altitude, Bitbit plants naturally grow from just nearby the sea $(3 \mathrm{~m})$ to south-eastern skirts of Mount Dranaz (985 m). After seed cleaning and germination tests, seeds were scarified and sown in small pots. In November of 2012, the seedlings were transplanted to the experimental field with $70 \times 70 \mathrm{~cm}$ spaces as 20 plants for each genotype. Measurements were realised on 10 plant samples for all genotypes in 2014. Plant height in spring was measured on $15^{\text {th }}$ of April. Last harvest was performed at the end of September and plant height data about autumn growing before winter were taken at the beginning of November. In 2014, 55 genotypes gave twice harvest but 31 genotypes only once. Statistical analysis performed amongst the traits with SPSS 17.0 program.

\section{Results and Discussion}

The altitude affected the measured traits negatively. As altitude increased, plant heights in autumn and spring, hay yield and harvest number decreased. While effect of altitude on elongation in autumn was statistically significant $\left(\mathrm{r}=-0.224^{*}\right)$, elongation in spring and number of harvest were statistically significant affected by altitude at level of $(\mathrm{P} \leq 0.01)$. More hay yield was obtained from the genotypes when elongations in autumn and spring were high. The genotypes with elongation earlier in spring, had higher hay yield and number of harvest (Table 1).

Table 1. Linear correlation values amongst the traits and their significance levels.

\begin{tabular}{l|ccccc}
\hline \multicolumn{1}{c|}{ Traits } & $\begin{array}{c}\text { Altitude } \\
(\mathrm{m})\end{array}$ & $\begin{array}{c}\text { Plant height in autumn } \\
(\mathrm{cm})\end{array}$ & $\begin{array}{c}\text { Plant height in spring } \\
(\mathrm{cm})\end{array}$ & $\begin{array}{c}\text { Hay yield } \\
(\mathrm{g} / \mathrm{plant})\end{array}$ & $\begin{array}{c}\text { Harvest } \\
\text { number }\end{array}$ \\
\hline Altitude & 1 & & & \\
Plant height in Autumn & $-0.224^{*}$ & 1 & 1 & \\
Plant height in Spring & $-0.417^{* *}$ & $0.363^{* *}$ & $0.433^{* *}$ & 1 \\
Hay yield & -0.096 & $0.278^{*}$ & $0.332^{* *}$ & $0.345^{* *}$ & 1 \\
Harvest number & $-0.337^{* *}$ & 0.064 &
\end{tabular}


Beside altitude, some other factors such as direction affect distribution of plant species. In south and southeastern skirts and valleys of mountains, plants can survive up to $985 \mathrm{~m}$ altitude on the other hand cold winds come from Siberia and Balkans through north and north-western directions, limited the adaptation of Bitbit plants to 400 $500 \mathrm{~m}$ altitudes.

The genotypes from high altitudes started elongation later than the others in spring (Figure 1). There was also slight elongation of those genotypes in autumn (Figure 2). Probably this is a cold hardening strategy developed by the plants like alfalfa. Dormant alfalfa cultivars have reduced shoot elongation and decumbent shoot orientation in autumn and are very winter hardy. Non-dormant cultivars have extensive shoot elongation with a vertical orientation in autumn and generally poor winter survival (Ventroni et al., 2010). The plants adapted to high altitudes generally have dormancy characteristics and they stay dormant in autumn, winter and early spring period to survive in harsh conditions (Kilinc and Kutbay, 2004). Bitbit genotypes adapted to high altitudes had less elongation in autumn and also started to elongate late in spring.

Regarding the altitude, as adaptation limits increased, the number of harvest was decreased (Figure 3). Unlike Figure 3, in Figure 4, the genotypes started elongation earlier in spring had more number of cutting. The

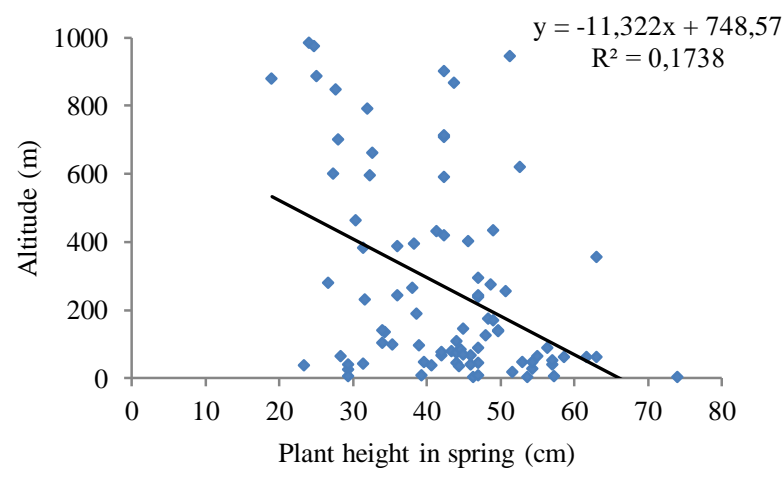

Figures 1. Relation between altitude and plant height in spring

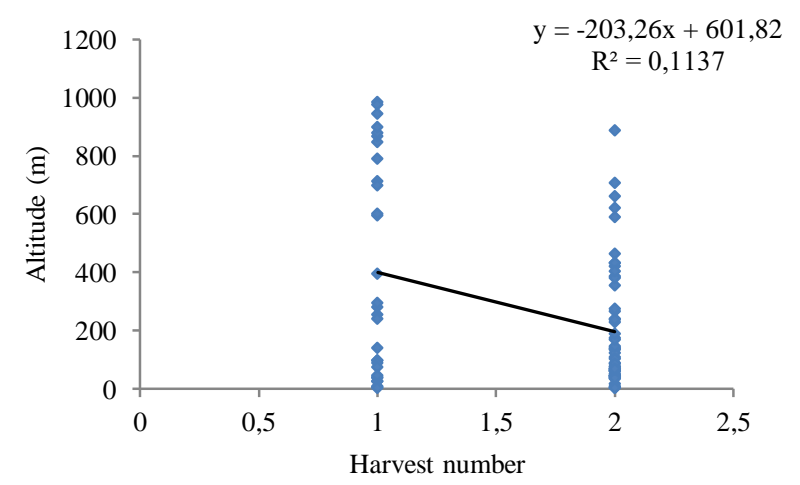

Figures 3. Relation between altitude and harvest number genotypes stayed dormant in winter, they started elongation late and natural consequence of this situation, number of harvest decreased. Some researchers determined clear differences amongst Bitbit genotypes in terms of cold tolerance, harvest number and hay yield (Correal, 2012; Real et al., 2014).

There were statistically significant correlation between hay yield and plant height in spring $\left(\mathrm{r}=0.433^{* *}\right)$ and in autumn $(\mathrm{r}=0.278 *)$ (Table 1 and Figures 5 and 6). The genotypes started elongation early in spring and continue their growth until autumn with higher hay yield than the others. Probably those genotypes have better regeneration ability of than the others. Furthermore, if a genotype started elongation early it has more time and natural resources for growing. Even if the plants keep growing and greenery in summer period, the best environmental conditions is in spring, thus earlier genotypes have much advantage compare to the others.

It is not surprised that increasing number of harvest causes increasing hay yield (Figure 7). Despite the decreasing hay yields through to sequencing harvests, the genotypes had higher number of harvest gave higher hay yield. There was a strong correlation between plant heights in spring and autumn $\left(\mathrm{r}=0.363^{* *}\right)$ (Table 1 and Figure 8$)$. The genotypes had more growth in autumn; they also started elongation earlier in spring due to no dormancy period.

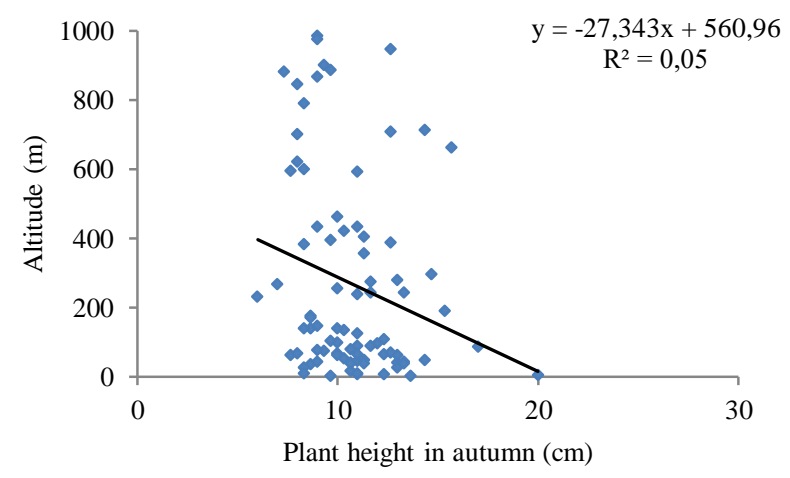

Figures 2. Relation between altitude and plant height in autumn

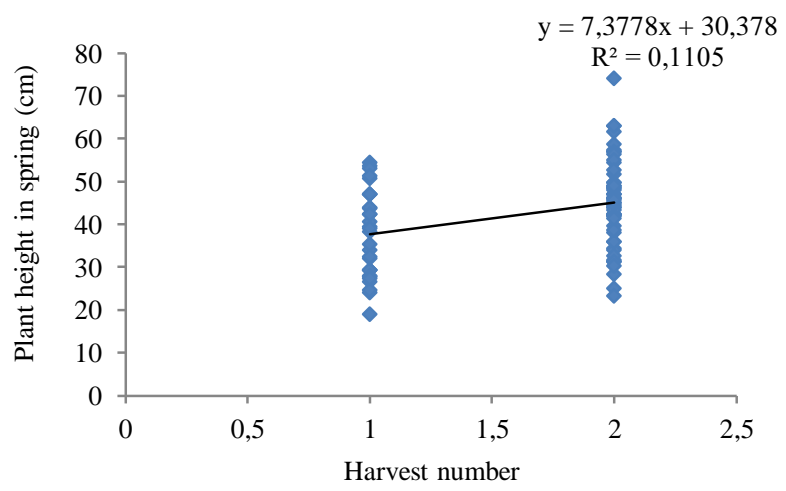

Figures 4. Relation between plant height in spring and harvest number 


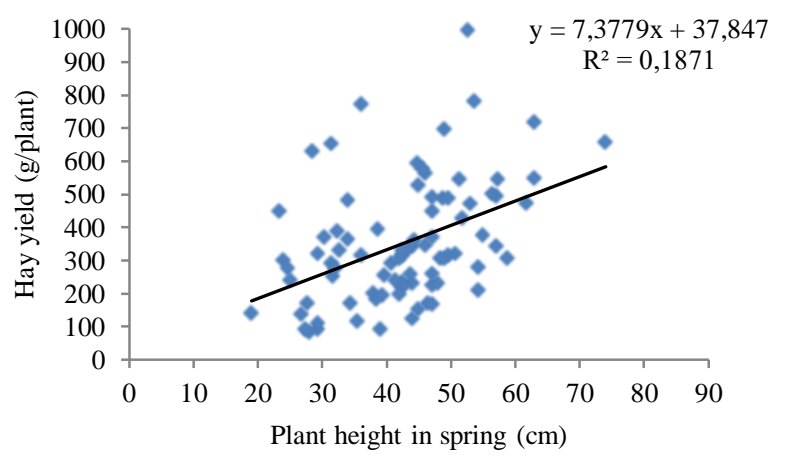

Figures 5. Relation between hay yield and plant height in spring

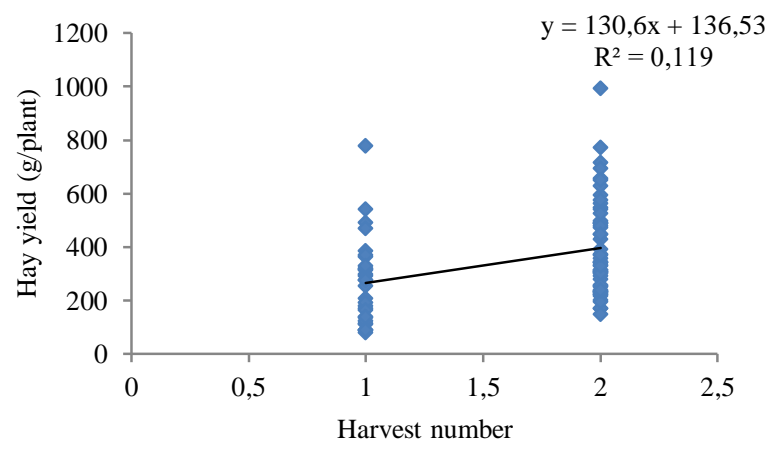

Figure 7. Relation between hay yield and harvest number

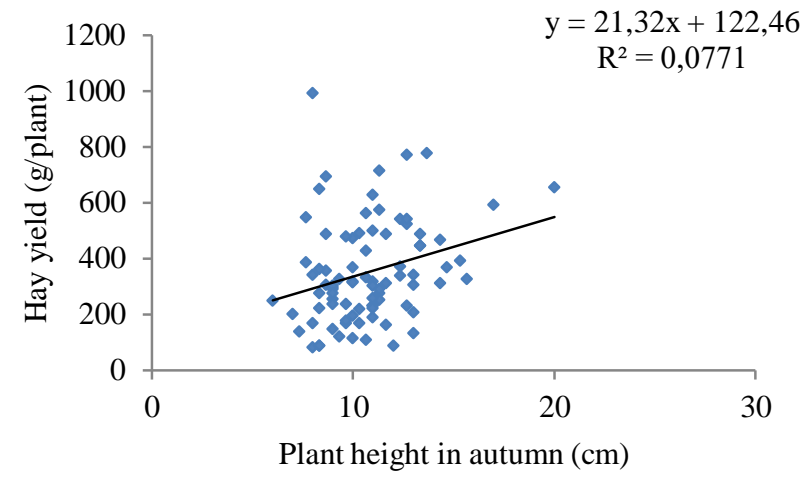

Figures 6. Relation between hay yield and plant height in autumn

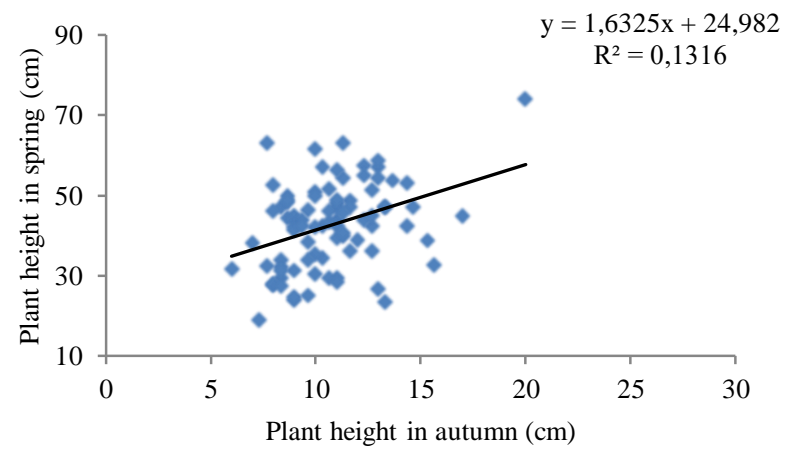

Figure 8. Relation between plant heights in spring and autumn

Annicchiarico P, Pecetti L, Abdelguerfi A, Bouizgaren A, Carroni AM, Hayek T, Mezni M. 2011. Adaptation of landrace and variety germplasm and selection strategies for lucerne in the Mediterranean basin. Field Crops Research, 120(2), 283-291. https://doi.org/10. 1016/j.fcr.2010.11.003

Anonymous. 2018. OECD-FAO Agricultural Outlook 2018-2027. http://www.fao.org/3/I9166EN/I9166EN.pdf

Correal E. 2012. Workshop on Suitable for Mediterranean Areas: The Case of Bituminaria spp. 28-30 November 2012, Sassari/Italy (Unpublished).

Cosentino SL, Gresta F, Testa G. 2013. Forage chain arrangement for sustainable livestock systems in a Mediterranean area. Grass and Forage Science, 69(4), 625-634.

Davis PH. 1970. Flora of Turkey and the East Aegean Islands. Vol. 3. Edinburgh

Dumont B, Andueza D, Niderkorn V, Luscher A, Porqueddu C, Picon-Cochard, C. 2015. A meta-analysis of climate change effects on forage quality in grasslands: Specificities of mountain and Mediterranean areas. Grass and Forage Science, 70, 239-254. https://doi.org/10.1111/gfs.12169

Finlayson J, Real D, Nordblom T, Revell C, Ewing M, Kingwell R. 2012. Farm level assessments of a novel drought tolerant forage: Tedera (Bituminaria bituminosa C.H. Stirt var. albomarginata). Agricultural Systems 112 (2012) 38-47

Giannakopoulos C, Le Sager P, Bindi M, Moriondo M, Kostopoulou E, Goodess CM. 2009. Climatic changes and associated impacts in the Mediterranean resulting from a $2{ }^{\circ} \mathrm{C}$ global warming. Global and Planetary Change, 68, 209-224. https://doi.org/10.1016/j.gloplacha. 2009.06.001

Huyghe C, De Vliegher A, van Gils B, Peeters A. 2014. Grasslands and herbivore production in Europe and effects of common policy. Quae Editions, 287 p 
Kilinç M, Kutbay HG. 2004. Plant Ecology. Palme press. Ankara, Turkey. P:432 (in Turkish).

Kilinç M, Kutbay HG, Akcin A. 1998. Flora of Kocadag and surroindings XIV. National Biology Congress, 7-10 September, 1998, Vol. I, p:95-111, Samsun, Turkey (in Turkish).

Lüscher A, Mueller-Harvey I, Soussana JF, Rees RM, Peyraud JL. 2014. Potential of legume-based grassland-livestock systems in Europe: a review, Grass Forage Science, 69, 206228, doi:10.1111/gfs.12124, 2014.

Melis RAM, Franca A, Re GA, Porqueddu C. 2018. Bioagronomic characterization and implications on the potential use as forage of Bituminaria bituminosa and B. morisiana accessions. Grass and forage science, 73(2), 284-296.

Mendez P, Santos A, Correal E, Rios S. 2006. Agronomic traits as forage crops of nineteen populations of Bituminaria bituminosa. In Sustainable grassland productivity: Proceedings of the 21st General Meeting of the European Grassland Federation, Badajoz, Spain, 3-6 April, 2006 (pp. 300-302). Sociedad Española para el Estudio de los Pastos (SEEP).
Neeman G, Goubitz S. 2000. Phenology of east-Mediterranean vegetation. In L. Trabaud (Ed.), Life and Environment in the Mediterranean. 155-201.

Pecetti L, Tava A, Romani M, De Benedetto MG, Corsi P. 2006. Variety and environment on the dynamics of saponins in lucerne (Medicago sativa L.). European Journal of Agronomy, 25, 187-192. https://doi.org/10.1016 /j.eja.2006.04.013

Porqueddu C, Ates S, Louhaichi M, Kyriazopoulos AP, Moreno G, del Pozo A, Nichols PGH. 2016. Grasslands in 'Old World' and 'New World' Mediterranean-climate zones: Past trends, current status and future research priorities. Grass and Forage Science, 71, 1-35. https://doi.org/10.1111/gfs.12212

Real D, Oldham CM, Nelson MN, Croser J, Castello M, Verbyla A, Pradhan A, Van Burgel A, Mendez P, Correal E, Teakle NL, Revel CK, Ewing MA. 2014. Evaluation and breeding of tedera for Mediterranean climates in southern Australia. Crop and Pasture Sciences, ttp://dx.doi.org /10.1071/CP13313.

Ventroni LM, Volenec JJ, Cangiano CA. 2010. Fall dormancy and cutting frequency impact on alfalfa yield and yield components. Field crops research, 119(2-3), 252-259. 